\title{
PERAN MEDIASI KEPUASAN KERJA PADA PENGARUH KEADILAN ORGANISASIONAL TERHADAP ORGANIZATIONAL CITIZENSHIP BEHAVIOR
}

\author{
Tjut Allya Magita Harumi ${ }^{1}$, I Gede Riana ${ }^{2}$ \\ ${ }^{1}$ Fakultas Ekonomi dan Bisnis, Universitas Udayana, tjutallya_magitaharumi@yahoo.com \\ ${ }^{2}$ Fakultas Ekonomi dan Bisnis, Universitas Udayana, gederiana@unud.ac.id
}

\begin{abstract}
ABSTRAK
Semakin meningkatnya kebutuhan masyarakat akan jasa perhotelan memicu berkembangnya bisnis perhotelan di Indonesia. Tujuan penelitian ini adalah untuk mengetahui peran kepuasan kerja dalam memediasi pengaruh keadilan organisasional terhadap OCB. Penelitian ini dilakukan pada Princess Keisha Hotel, Denpasar. Penelitian ini menggunakan sampel jenuh, dimana menggunakan keseluruhan populasi yaitu 40 orang sebagai unit analisis. Data di analisis menggunakan teknik analisis jalur (Path Analysis). Hasil penelitian menunjukkan bahwa keadilan organisasional berpengaruh positif dan signifikan terhadap kepuasan kerja, keadilan organisasional berpengaruh positif dan signifikan terhadap Organizational Citizenship Behavior (OCB), kepuasan kerja berpengaruh positif dan signifikan terhadap Organizational Citizenship Behavior (OCB), serta kepuasan kerja secara positif dan signifikan memediasi keadilan organisasional terhadap Organizational Citizenship Behavior (OCB).

Kata Kunci: Keadilan Organisasional, Kepuasan Kerja, Organizational Citizenship Behavior (OCB)
\end{abstract}

\begin{abstract}
The increasing demand for hospitality services has triggered the development of the hospitality business in Indonesia. The purpose of this study was to determine the role of job satisfaction in mediating the effect of organizational justice on OCB. This research was conducted at Princess Keisha Hotel, Denpasar. This study uses a saturated sample, which uses an entire population of 40 people as a unit of analysis. Data analyzed using Path Analysis techniques. The results showed that organizational justice has a positive and significant effect on job satisfaction, organizational justice has a positive and significant effect on Organizational Citizenship Behavior (OCB), job satisfaction has a positive and significant effect on Organizational Citizenship Behavior (OCB), and job satisfaction is positive and significantly mediates organizational justice towards Organizational Citizenship Behavior (OCB).

Keywords: Organizational Justice, Job Satisfaction, Organizational Citizenship Behavior (OCB)
\end{abstract}

\section{PENDAHULUAN}

Pariwisata merupakan industri yang mengalami pertumbuhan yang cepat di Indonesia. Bali merupakan salah satu daerah destinasi pariwisata di Indonesia yang banyak diminati oleh wisatawan lokal maupun mancanegara. Keindahan alam dan kebudayaan Bali yang unik dan beranekaragam serta keindahan alam menjadi daya tarik tersendiri bagi para wisatawan. Perusahaan yang bersaing dalam bisnis pariwisata salah satunya adalah bisnis jasa perhotelan. Hotel merupakan faktor pendukung pariwisata yang mempunyai peran penting dalam mengembangkan sarana dan prasarana pariwisata. Perusahaan harus mampu berkompetisi dan berusaha agar tetap bertahan dari segala jenis persaingan yang akan terjadi, untuk dapat bersaing maka perusahaan harus selalu memperhatikan kinerja SDMnya karena sumber daya manusia merupakan aset penting dalam perusahaan. 
Sumber daya manusia merupakan faktor yang dapat menciptakan identitas dalam perusahaan yang tidak dapat diduplikasi oleh para pesaingnya sehingga dapat menghasilkan keuntungan yang lebih dibandingkan pesaingnya (Erkutlu, 2011). Perusahaan yang memiliki sumber daya manusia yang baik akan berdampak langsung pada kemajuan perusahaan dan dapat mencapai tujuan perusahaan. Peningkatan efektifitas dan keberhasilan sebuah organisasi sangat tergantung pada pengelolaan sumber daya manusia yang baik, dikarenakan perusahaan harus dapat memiliki sumber daya manusia yang disiplin, profesional, tanggung jawab, dan beritegritas tinggi kepada perusahaannya (Prameswari dan Suwandana, 2017).

Organisasi dapat meningkatkan produktivitasnya dengan menerapkan perilaku Organizational Citizenship Behaviour (OCB) atau perilaku Extra-role (Lubis, 2015). Pegawai yang tidak hanya mengerjakan tugas pokoknya saja namun bersedia melakukan tugas tambahan seperti mau bekerja sama, membantu rekan kerja, serta mau menggunakan waktu kerjanya dengan efektif tanpa imbalan apapun akan membuat organisasi berhasil mencapai tujuannya itu disebut sebagai OCB (Nugraha dan Adnyani, 2018). Seseorang dengan perilaku OCB yang tinggi rela tidak dibayar dalam bentuk uang atau bonus tertentu, tetapi lebih kepada perilaku sosial dari masing-masing karyawan untuk bekerja melebihi apa yang diharapkan oleh perusahaan (Ahdiyana, 2013).

Menurut Santika dan Wibawa (2017), perilaku OCB pada karyawan dipengaruhi oleh beberapa faktor di antaranya faktor yang berhubungan dengan keadilan organisasional. Menurut Putra dan Supartha (2016), OCB merupakan kunci kesuksesan suatu organisasi, misalnya ketika timbal balik yang didapatkan karyawan tidak sesuai dengan yang diharapkan atau tidak adil maka kemungkinan besar karyawan akan kehilangan ketertarikannya untuk menerapkan perilaku OCB. Luthans (2006), menyatakan bahwa karyawan harus diperlakukan secara adil dalam aturan maupun hasil yang diterima agar dapat membangun perilaku OCB.

Menurut Nandan dan Azim (2015), keadilan organisasional adalah sebuah konsep persepsi karyawan mengenai sejauh mana mereka diperlakukan secara adil dalam organisasi. Ketidakadilan dalam organisasi tidak hanya mengurangi prestasi kerja tetapi juga mengurangi kualitas pekerjaan dan kerjasama antara pekerja (Awang dan Ahmad, 2015). Ketidakadilan dapat menimbulkan tidak adanya ikatan yang terjalin antar anggota organisasi dan dapat menyakiti individu serta membahayakan bagi perusahaan (Mustikawati dan Suana, 2018). Ketidakadilan yang dibiarkan berlarut-larut dapat menyebabkan perilaku menyimpang di tempat kerja (Sanhaji dkk., 2016).

Gibson et al. (2012) mendefinisikan keadilan organisasional sebagai tingkat di mana seorang individu merasa diperlakukan sama di dalam organisasi tempat dia bekerja. Ketidakadilan dalam organisasi akan mengakibatkan ketidakpuasan yang dapat menyebabkan perilaku menyimpang ditempat kerja, seperti lebih malas bekerja, mengabaikan aturan perushaan, dan lain sebagainya. Perlakuan adil di tempat kerja memungkinkan dapat meningkatkan kepuasan kerja para anggota kelompok (Cropanzano et al. 2007). Moorman (1991), menyataka bahwa keadilan organisasional dapat mempengaruhi kepuasan kerja. Salah satu faktor yang dapat mempengaruhi kepuasan kerja dalam organisasi adalah keadilan organisasional (Naeem et al. 2014).

Ketidakpuasan akan menimbulkan masalah di dalam organisasi yang akan menyebabkan terjadinya penurunan kinerja karyawan. Menurut Anas (2013), apabila kepuasan kerja karyawan terjaga, maka akan mengakibatkan semangat kerja yang tinggi yang dapat membantu pihak perusahaan dalam mencapai tujuan yang diinginkan perusahaan. Naeem et al. (2014), mengatakan bahwa organisasi sangat perlu adanya 
kepuasan kerja karena akan memiliki dampak yang baik bagi perusahaan. Kepuasan kerja dapat dilihat dari kenyamanan seorang karyawan dalam mengerjakan tugas yang diberikan oleh perusahaan (Bakotic dan Babic, 2013). Menurut Santhi dan Mujiati (2016), dalam organisasi sangat diperlukan menjaga hubungan yang baik antar pegawai untuk menghantarkan pegawai mencapai kepuasan kerjanya.

Menurut Robbins dan Judge (2008:113), karyawan yang memiliki kepuasan terhadap pekerjaanya akan melakukan hal positif terhadap organisasi seperti membantu pekerja lain dan melewati harapan normal dalam pekerjaan mereka, maka kepuasan kerja adalah faktor utama dari perilaku OCB. Karyawan yang merasa puas akan bersedia melakukan segala hal untuk perusahaan yang pada akhirnya menimbulkan OCB (Mohammad et al., 2011). Menurut Saepung et al. (2011), dimana kepuasan kerja baik intrinsik maupun ekstrinsik dapat mempengaruhi OCB. Rahmi (2014), menunjukan bahwa adanya pengaruh kepuasan kerja terhadap OCB, jadi apabila kepuasan kerja seseorang semakin tinggi maka semakin tinggi pula tingkat perilaku OCB yang ditimbulkan.

Menurut Widyaningrum (2010), kepuasan kerja terbukti mampu memediasi secara penuh pengaruh keadilan organisasional terhadap OCB. Kepuasan kerja memediasi hubungan antara keadilan organisasional dan OCB (Saifi dan Shahzad, 2017). Penelitian dari Najafi et al., (2011), menyatakan bahwa kepuasan kerja dapat memediasi hubungan antara keadilan organisasional dengan OCB.

Berdasarkan paparan di atas maka permasalahan penelitian apakah keadilan organisasional berpengaruh terhadap kepuasan kerja, apakah kepuasan kerja berpengaruh terhadap Organizational Citizenship Behavior (OCB), apakah keadilan organisasional berpengaruh terhadap Organizational Citizenship Behavior (OCB), dan apakah kepuasan kerja memediasi pengaruh keadilan organisasional terhadap Organizational Citizenship Behavior (OCB). Sehingga penelitian ini ditujukan untuk menganalisis pengaruh keadilan organisasional terhadap kepuasan kerja, menganalisis pengaruh kepuasan kerja terhadap Organizational Citizenship Behavior (OCB), menganalisis pengaruh keadilan organisasional terhadap Organizational Citizenship Behavior (OCB), dan menganalisis peran mediasi kepuasan kerja pada pengaruh keadilan organisasional terhadap Organizational Citizenship Behavior (OCB).

\section{TINJAUAN LITERATUR}

\section{Penelitian Terdahulu}

Menurut penelitian yang dilakukan Altahayneh et al. (2014), menunjukkan bahwa keadilan organisasional berpengaruh positif dan signifikan terhadap kepuasan kerja. Penelitian dari Putra dan Putra (2014), menunjukan bahwa keadilan organisasional berpengaruh positif pada kepuasan kerja karyawan. Kristanto dkk. (2014), mengatakan bahwa keadilan organisasional berpengaruh positif dan signifikan terhadap kepuasan kerja. Putri (2015), menemukan hasil bahwa keadilan organisasional berpengaruh signifikan terhadap kepuasan kerja.

Lembono (2013), juga menyatakan kepuasan kerja berpengaruh positif dan signifikan terhadap OCB, semakin tinggi tingkat kepuasan kerja yang di dapat maka semakin tinggi juga tingkat OCB yang dilaksanakan. Wijaya dan Sutanto (2014), menunjukkan bahwa kepuasan kerja berpengaruh positif dan signifikan terhadap organizational citizenship behavior. Penelitian yang dilakukan oleh Rohayati (2014), menyatakan bahwa variabel kepuasan kerja berpengaruh positif dan signifikan terhadap 
OCB. Rejeki dkk. (2014), dalam penelitiannya menemukan bahwa kepuasan kerja berpengaruh positif dan signifikan terhadap OCB.

Nwibere (2014), membuktikan bahwa keadilan organisasional memiliki pengaruh positif dan signifikan terhadap Organizational Citizenship Behavior (OCB). Ibrahim dan Perez (2014), menunjukkan bahwa keadilan organisasional berpengaruh postitif terhadap organizational citizenship behavior. Roohi dan Feizi (2013), menyimpulkanv bahwa keadilan organisasional berpengaruh postitif terhadap organizational citizenship behavior. Menurut Saifi dan Shahzad (2017), Keadilan organisasional memiliki dampak positif yang signifikan terhadap OCB.

Kepuasan kerja memediasi hubungan antara keadilan organisasional dan OCB (Saifi dan Shahzad, 2017). Penelitian dari Najafi et al., (2011), menyatakan bahwa kepuasan kerja dapat memediasi hubungan antara keadilan organisasional dengan OCB. Zadeh et al. (2015), mengatakan bahwa keadilan organisasional berpengaruh terhadap OCB dengan kepuasan kerja sebagai pemediasi. Menurut Fatimah et al. (2011), dalam penelitiannya terdapat hubungan positif antara keadilan orgnisasional dan kepuasan kerja dengan OCB.

\section{Organizational Citizenship Behavior (OCB)}

Harper (2015), menyatakan bahwa perilaku yang dapat meningkatkan produktivitas karyawan di dalam perusahaan yaitu Organizational Citizenship Behavior (OCB). Organizational Citizenship Behavior (OCB) ditekankan untuk mempererat ikatan sosial yang dimiliki oleh seorang karyawan dengan rekan kerja dan organisasinya sendiri (Supartha dkk., 2013). Karyawan yang merasa percaya diri atas kemampuan mereka untuk menjalankan tugasnya dapat mempengaruhi karyawan untuk rela melakukan OCB (Lee et al., 2013). Organisasi yang memiliki karyawan yang rela bekerja melebihi tanggungjawabnya dan secara sukarela memberikan waktu dan tenaganya demi kesuksesan organisasi disebut juga dengan OCB (Sjahruddin dan Normijati, 2013). Suryanatha dan Ardana (2014), menyatakan perilaku karyawan yang melaksanakan tugasnya dengan baik secara sukarela tanpa harus dikendalikan dan diperintah oleh atasannya disebut dengan organizational citizenship behavior (OCB).

\section{Keadilan Organisasional}

Menurut Ogut et al. (2013), apabila atasan di dalam organisasi berlaku adil terhadap karyawannya maka hubungan kerjasama antara atasan dengan karyawannya akan lebih baik sehingga keputusan yang diambil oleh atasan dapat diterima oleh karyawannya. Menurut Tahseen dan Akhtar (2016), yang perlu perusahaan utamakan di dalam keadilan organisasional adalah karyawan harus merasa bahwa mereka diperlakukan dengan adil dalam suatu organisasi. Perlakuan tidak adil mengacu pada praktik dimana seseorang diperlakukan berbeda atas dasar alasan yang tidak seharusnya (Svensson dan Genugten, 2013). Konsep keadilan digunakan untuk menjelaskan mengapa karyawan dapat menilai wajar atau tidaknya keputusan yang dibuat oleh pihak yang berwenang (Roohi dan Feizi, 2013). Farahbod et al. (2013), mengatakan bahwa keadilan organisasional dapat diartikan sebagai kesetaraan di tempat kerja.

\section{Kepuasan Kerja}

Kepuasan kerja merupakan perasaan menyenangkan yang ditimbulkan dari keberhasilan dalam menyelesaikan tugas (Rini dkk., 2013). Rasa senang pun akan datang apabila karyawan merasa puas dengan pekerjaan yang dilakukannya, sehingga akan menciptakan rasa aman dan nyaman dalam bekerja (Indrawan dan Dewi, 2014). 
Kepuasan karyawan pada pekerjaan mereka dianggap sebagai salah satu faktor penting bagi kesuksesan dan kelangsungan hidup organisasi (Ibrahim et al., 2014). Kepuasan kerja adalah gambaran secara khusus seorang karyawan terhadap pekerjaannya (Yaqin, 2013). Mohammed dan Eleswed (2013), menyatakan bahwa karyawan yang puas terhadap perkerjaannya cenderung lebih setia dan fleksibel terhadap perkerjaannya. Kepuasan kerja yang diterima oleh karyawan dapat meningkatkan kinerja karyawan di dalam organisasi (Swaminathan dan Jawahar, 2013).

\section{METODOLOGI}

Pendekatan yang digunakan dalam penelitian ini adalah pendekatan kuantitatif yang berbentuk kausalitas (regresi). Penelitian ini menguji hipotesis yang menjelaskan pengaruh keadilan organisasional terhadap kepuasan kerja, pengaruh kepuasan kerja terhadap Organizational Citizenship Behavior (OCB), pengaruh keadilan organisasional terhadap Organizational Citizenship Behavior (OCB), dan kepuasan kerja dalam memediasi pengaruh keadilan organisasional terhadap Organizational Citizenship Behavior (OCB).

Lokasi penelitian ini adalah pada Princess Keisha Hotel yang beralamat di Jalan Teuku Umar Barat No. 350, Denpasar, Bali. Alasan peneliti melakukan penelitian di Princess Keisha Hotel yaitu karena peneliti melihat adanya permasalahan yang menyangkut OCB, keadilan organisasional dan kepuasan kerja pada hotel ini.

Populasi yang digunakan dalam penelitian ini adalah seluruh karyawan yang bekerja pada Princess Keisha Hotel yang berjumlah 40 orang. Sampel jenuh adalah teknik penentuan sampel apabila jumlah populasi relatif kecil atau kurang dari 100 orang, atau penelitian yang ingin membuat generalisasi dengan kesalahan yang sangat kecil. Berdasarkan uraian diatas, besarnya sampel yang diteliti berjumlah 40 orang.

Pengumpulan data dilakukan dengan digunakannya kuesioner dengan menggunakan metode pengumpulan data skala likert yang digunakan memiliki lima tingkatan yang merupakan skala jenis ordinal. Variabel yang diukur dijabarkan menjadi indikator variabel, kemudian indikator tersebut dijadikan sebagai titik tolak untuk menyusun item-item instrumen yang dapat berupa pernyataan atau pertanyaan. Jawaban setiap item instrumen diberi skor dengan perbandingan sebagai berikut:

$\begin{array}{ll}\text { Sangat Setuju (SS) } & =5 \\ \text { Setuju (S) } & =4 \\ \text { Netral (N) } & =3 \\ \text { Tidak Setuju (TS) } & =2 \\ \text { Sangat Tidak Setuju (STS) } & =1\end{array}$

Teknik analisis data yang digunakan dalam penelitian ini adalah analisis jalur (Path Analysis).

Persamaan Sub-struktural 1

$$
M=\beta_{2} X+e_{1}
$$

Persamaan Sub-struktural 2

$$
\mathrm{Y}=\beta_{1} \mathrm{X}+\beta_{3} \mathrm{M}+\mathrm{e}_{2}
$$

Keterangan:

$$
\begin{array}{ll}
\mathrm{Y} & =\text { Organizational Citizenship Behavior }(\mathrm{OCB}) \\
\mathrm{X} & =\text { Keadilan organisasional } \\
\mathrm{M} & =\text { Kepuasan kerja } \\
\beta_{1}, \beta_{2}, \beta_{3} & =\text { Koefisien regresi variabel } \\
\mathrm{e} & =\text { Error }
\end{array}
$$




\section{HASIL DAN PEMBAHASAN}

Hasil uji validitas instrumen penelitian disajikan pada Tabel 1 yang menunjukkan bahwa seluruh indikator pertanyaan dalam variabel Organizational Citizenship Behavior (OCB), keadilan organisasional, dan kepuasan kerja memiliki nilai koefisien korelasi yang lebih besar dari angka 0,30 sehingga hal ini menunjukkan bahwa butir-butir pernyataan dalam instrumen penelitian tersebut valid.

Tabel 1. Rekapitulasi Hasil Uji Validitas Instrumen Penelitian

\begin{tabular}{|c|c|c|c|c|}
\hline \multirow{2}{*}{ Variabel } & \multirow{2}{*}{ Indikator } & Koefisien & \multirow{2}{*}{ Sig. (2-tailed) } & \multirow{2}{*}{ Keterangan } \\
\hline & & Korelasi & & \\
\hline \multirow{11}{*}{$\begin{array}{l}\text { Organizational } \\
\text { Citizenship } \\
\text { Behavior (Y) }\end{array}$} & Y1 & 0,906 & 0,000 & Valid \\
\hline & Y2 & 0,887 & 0,000 & Valid \\
\hline & Y3 & 0,858 & 0,000 & Valid \\
\hline & $\mathrm{Y} 4$ & 0,838 & 0,000 & Valid \\
\hline & Y5 & 0,766 & 0,000 & Valid \\
\hline & Y6 & 0,872 & 0,000 & Valid \\
\hline & Y7 & 0,808 & 0,000 & Valid \\
\hline & Y8 & 0,939 & 0,000 & Valid \\
\hline & Y9 & 0,894 & 0,000 & Valid \\
\hline & Y10 & 0,651 & 0,000 & Valid \\
\hline & $\mathrm{X} 1$ & 0,921 & 0,000 & Valid \\
\hline \multirow{5}{*}{$\begin{array}{l}\text { Keadilan } \\
\text { Organisasional (X) }\end{array}$} & $\mathrm{X} 2$ & 0,767 & 0,000 & Valid \\
\hline & $\mathrm{X} 3$ & 0,905 & 0,000 & Valid \\
\hline & $\mathrm{X} 4$ & 0,795 & 0,000 & Valid \\
\hline & $\mathrm{X} 5$ & 0,921 & 0,000 & Valid \\
\hline & $\mathrm{X} 6$ & 0,760 & 0,000 & Valid \\
\hline \multirow{10}{*}{$\begin{array}{l}\text { Kepuasan Kerja } \\
\text { (M) }\end{array}$} & M1 & 0,820 & 0,000 & Valid \\
\hline & M2 & 0,737 & 0,000 & Valid \\
\hline & M3 & 0,839 & 0,000 & Valid \\
\hline & M4 & 0,883 & 0,000 & Valid \\
\hline & M5 & 0,778 & 0,000 & Valid \\
\hline & M6 & 0,795 & 0,000 & Valid \\
\hline & M7 & 0,863 & 0,000 & Valid \\
\hline & M8 & 0,827 & 0,000 & Valid \\
\hline & M9 & 0,850 & 0,000 & Valid \\
\hline & M10 & 0,684 & 0,000 & Valid \\
\hline
\end{tabular}

Sumber: Data diolah, 2018

Hasil uji validitas pada Tabel 1 menunjukkan bahwa seluruh instrumen penelitian yang digunakan untuk mengukur variabel Organizational Citizenship Behavior, keadilan organisasional dan kepuasan kerja memiliki nilai koefisien korelasi dengan skor total seluruh item pernyataan lebih besar dari 0,30 dengan signifikansi kurang dari 0,05. Hal ini menunjukkan bahwa butir-butir pernyataan dalam instrumen penelitian tersebut valid dan layak digunakan sebagai instrumen penelitian.

Uji Reliabilitas terhadap instrumen penelitian ini menggunakan nilai Alpha Cronbach, yakni untuk mengetahui unidimensionalitas butir-butir pernyataan terhadap variabel laten yang diteliti. Nilai Alpha Cronbach dinyatakan reliabel jika nilainya lebih besar atau sama dengan 0,60. Rekapitulasi hasil uji reliabilitas instrumen penelitian dapat dilihat pada Tabel 2 berikut. 
Tabel 2. Rekapitulasi Hasil Uji Reliabilitas Instrumen Penelitian

\begin{tabular}{llll}
\hline No. & Variabel & $\begin{array}{l}\text { Cronbach's } \\
\text { Alpha }\end{array}$ & Keterangan \\
\hline 1 & Organizational Citizenship Behavior (Y) & 0,954 & Reliabel \\
2 & Keadilan Organisasional (X) & 0,920 & Reliabel \\
3 & Kepuasan Kerja (M) & 0,940 & Reliabel \\
\hline
\end{tabular}

Sumber: Data Diolah, 2018

Hasil uji reliabilitas yang disajikan dalam Tabel 2 menunjukkan bahwa seluruh instrumen penelitian memiliki koefisien Cronbach's Alpha lebih dari 0,60. Jadi dapat dinyatakan bahwa seluruh variabel telah memenuhi syarat reliabilitas atau kehandalan sehingga dapat digunakan untuk melakukan penelitian.

Perhitungan koefisien path dilakukan dengan analisis regresi melalui software SPSS 22.0 for Windows, diperoleh hasil yang ditunjukan pada Tabel 3 berikut.

Tabel 3. Hasil Analisis Jalur 1

\begin{tabular}{lllll}
\hline \multicolumn{1}{c}{ Variabel } & Standardized Coefficients & Std. Error & t hitung & Sig. uji t \\
\hline (Constant) & 0,226 & 0,261 & 0,867 & 0,391 \\
Keadilan Organisasional (X) & 0,912 & 0,067 & 13,710 & 0,000 \\
R Square & 0,832 & & & \\
F Statistik & 187,971 & & & \\
Signifikansi Uji F & 0,000 & & & \\
\hline S
\end{tabular}

Sumber: Data diolah, 2018

Berdasarkan hasil analisis jalur substruktur 1 seperti yang disajikan pada Tabel 3, maka dapat dibuat persamaan struktural sebagai berikut:

$$
\begin{aligned}
& \mathrm{M}=\beta_{1} \mathrm{X}+\mathrm{e}_{1} \\
& \mathrm{M}=0,912 \mathrm{X}+\mathrm{e}_{1}
\end{aligned}
$$

Nilai koefisien regresi variabel keadilan organisasional bernilai positif dengan nilai signifikansi uji t kurang dari 0,05 . Hal ini menunjukkan bahwa variabel keadilan organisasional memiliki pengaruh positif yang signifikan terhadap variabel kepuasan kerja. Besarnya pengaruh variabel bebas terhadap variabel terikat yang ditunjukkan oleh nilai determinasi total ( $R$ Square) sebesar 0,832 mempunyai arti bahwa sebesar 83,2\% variasi kepuasan kerja dipengaruhi oleh variasi keadilan organisasional, sedangkan sisanya sebesar $16,8 \%$ dijelaskan oleh faktor lain yang tidak dimasukkan ke dalam model.

Tabel 4. Hasil Analisis Jalur 2

\begin{tabular}{lllll}
\hline Variabel & Standardized Coefficients & Std. Error & t hitung & Sig. uji t \\
\hline (Constant) & 0,108 & 0,288 & 0,374 & 0,710 \\
Keadilan Organisasional (X) & 0,459 & 0,179 & 2,733 & 0,010 \\
Kepuasan kerja (M) & 0,470 & 0,177 & 2,795 & 0,008 \\
R Square & 0,824 & & & \\
F Statistik & 86,843 & & & \\
Signifikansi Uji F & 0,000 & & & \\
\hline
\end{tabular}

Sumber: Data diolah, 2018

Berdasarkan hasil analisis jalur substruktur 2 seperti yang disajikan pada Tabel 4.14, maka dapat dibuat persamaan struktural sebagai berikut:

$$
\mathrm{Y}=\beta_{2} \mathrm{X}+\beta_{3} \mathrm{M}+\mathrm{e}_{2}
$$




$$
\mathrm{Y}=0,459 \mathrm{X}+0,470 \mathrm{M}+\mathrm{e}_{2}
$$

Nilai koefisien regresi masing-masing variabel bebas bernilai positif dengan nilai signifikansi uji t kurang dari 0,05. Hal ini menunjukkan bahwa semua variabel bebas memiliki pengaruh positif yang signifikan terhadap variabel terikat. Besarnya pengaruh variabel bebas terhadap variabel terikat yang ditunjukkan oleh nilai determinasi total ( $R$ Square) sebesar 0,824 mempunyai arti bahwa sebesar $82,4 \%$ variasi Organizational Citizenship Behavior (OCB) dipengaruhi oleh variasi keadilan organisasional dan kepuasan kerja, sedangkan sisanya sebesar 17,6\% dijelaskan oleh faktor lain yang tidak dimasukkan ke dalam model.

Berdasarkan model substruktur 1 dan substruktur 2, maka dapat disusun model diagram jalur akhir. Sebelum menyusun model diagram jalur akhir, terlebih dahulu dihitung nilai standar eror sebagai berikut:

$$
\begin{aligned}
& \mathrm{Pe}_{\mathrm{i}}=\sqrt{1-\mathrm{R}_{\mathrm{i}}{ }^{2}} \\
& \mathrm{Pe}_{1}=\sqrt{1-{R_{1}}^{2}}=\sqrt{1-0,832}=0,409 \\
& \mathrm{Pe}_{2}=\sqrt{1-R_{2}{ }^{2}}=\sqrt{1-0,824}=0,419
\end{aligned}
$$

Berdasarkan perhitungan pengaruh error (Pei), didapatkan hasil pengaruh error $\left(\mathrm{Pe}_{1}\right)$ sebesar 0,409 dan pengaruh error $\left(\mathrm{Pe}_{2}\right)$ sebesar 0,419. Hasil koefisien determinasi total adalah sebagai berikut:

$$
\begin{aligned}
\mathrm{R}^{2} \mathrm{~m} & =1-\left(\mathrm{Pe}_{1}\right)^{2}\left(\mathrm{Pe}_{2}\right)^{2} \\
& =1-(0,409)^{2}(0,419)^{2} \\
& =1-(0,167)(0,175) \\
& =1-0,029=0,971
\end{aligned}
$$

Nilai determinasi total sebesar 0,971 mempunyai arti bahwa sebesar 97,1\% variasi organizational citizenship behavior (OCB) dipengaruhi oleh variasi keadilan organisasional dan kepuasan kerja, sedangkan sisanya sebesar 2,9\% djelaskan oleh faktor lain yang tidak dimasukkan ke dalam model.

Hasil koefisien jalur pada hipotesis penelitian dapat digambarkan pada Gambar 4.3 berikut:

Berdasarkan diagram jalur pada Gambar 1, maka dapat dihitung besarnya pengaruh langsung dan pengaruh tidak langsung serta pengaruh total antar variabel.

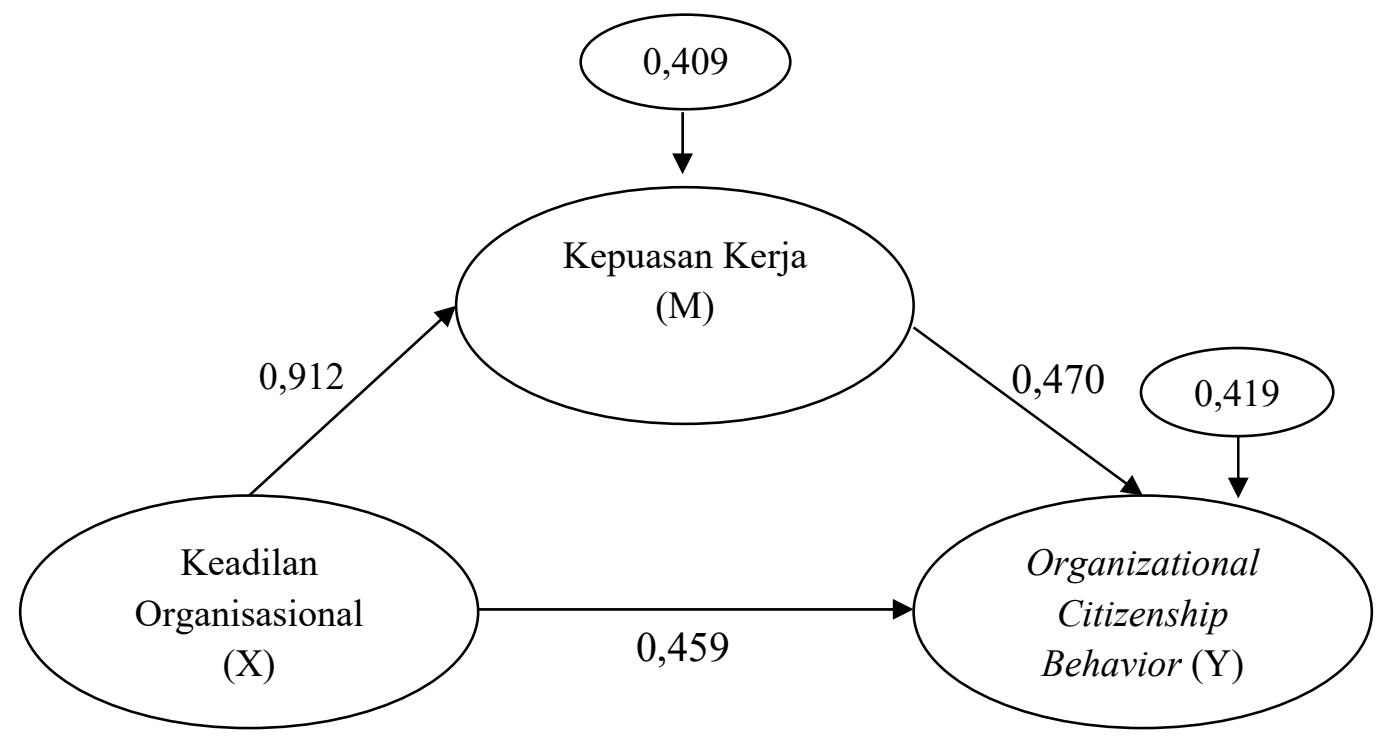

Gambar 1.

Validasi Model Diagram Jalur Akhir

100 | Peran Mediasi Kepuasan Kerja Pada Pengaruh Keadilan Organisasional... 
Perhitungan pengaruh antar variabel dirangkum dalam Tabel 5 sebagai berikut.

Tabel 5. Pengaruh Langsung dan Pengaruh Tidak Langsung serta Pengaruh Total Keadilan Organisasional (X), Kepuasan Kerja (M), dan Organizational Citizenship Behavior (Y)

\begin{tabular}{cccc}
\hline $\begin{array}{c}\text { Pengaruh } \\
\text { Variabel }\end{array}$ & $\begin{array}{c}\text { Pengaruh } \\
\text { Langsung }\end{array}$ & $\begin{array}{c}\text { Pengaruh Tidak Langsung Melalui } \\
\text { Kepuasan Kerja } \\
(\mathbf{M})(\boldsymbol{\beta} \mathbf{1} \text { } \boldsymbol{\beta 3})\end{array}$ & $\begin{array}{c}\text { Pengaruh } \\
\text { Total }\end{array}$ \\
\hline $\mathrm{X} \rightarrow \mathrm{M}$ & 0,912 & - & 0,912 \\
$\mathrm{X} \rightarrow \mathrm{Y}$ & 0,459 & 0,428 & 0,887 \\
$\mathrm{M} \rightarrow \mathrm{Y}$ & 0,470 & - & 0,470 \\
\hline
\end{tabular}

Sumber: Data diolah, 2018

Uji sobel dihitung dengan rumus dibawah ini:

$$
\begin{aligned}
& Z=\frac{a b}{\sqrt{\mathrm{a}^{2} \mathrm{~S}_{\mathrm{b}}{ }^{2}+\mathrm{b}^{2} \mathrm{~S}_{\mathrm{a}}^{2}+\mathrm{S}_{\mathrm{a}}^{2} \mathrm{~S}_{\mathrm{b}}^{2}}} \\
& \mathrm{Sig}=(1-\operatorname{NORMDIST}(\mathrm{Z})) 2)) \\
& \text { Keterangan: }=0,912 \\
& \mathrm{a} \quad= 0,067 \\
& \mathrm{Sa} \quad=0,470 \\
& \mathrm{Sb} \quad=0,177 \\
& \quad Z=\frac{0,912.0,470}{\sqrt{0,912^{2} 0,177^{2}+0,470^{2} 0,067^{2}+0,067^{2} 0,177^{2}}} \\
& Z=\frac{0,4286}{\sqrt{0,0261+0,0010+0,0001}} \\
& Z=\frac{0,4286}{\sqrt{0,0272}} \\
& \mathbf{Z}=\mathbf{2 , 5 9 9 5}
\end{aligned}
$$

Tabel 6. Hasil Uji Sobel

\begin{tabular}{cc}
\hline Nilai $Z$ & Sig \\
\hline 2,5995 & 0,0093 \\
\hline
\end{tabular}

Sumber: Data diolah, 2018

Berdasarkan hasil uji sobel pada Tabel 6 menunjukan bahwa nilai $\mathrm{Z}$ hitung sebesar 2,5995 $>1,96$ dengan nilai signifikansi $0,0093<0,05$, yang artinya kepuasan kerja merupakan variabel yang memediasi pengaruh keadilan organisasional terhadap Organizational Citizenship Behavior (OCB) pada Princess Keisha Hotel atau dengan kata lain keadilan organisasional berpengaruh secara tidak langsung terhadap Organizational Citizenship Behavior (OCB) melalui kepuasan kerja. 


\section{PEMBAHASAN}

Hasil pengujian hipotesis pengaruh keadilan organisasional terhadap Organizational Citizenship Behavior (OCB) diperoleh nilai Signifikansi sebesar 0,010 dengan nilai koefisien beta 0,459. Nilai Signifikansi $0,010<0,05$ mengindikasikan bahwa $\mathrm{H}_{0}$ ditolak dan $\mathrm{H}_{2}$ diterima. Hasil ini mempunyai arti bahwa keadilan organisasional berpengaruh positif dan signifikan terhadap Organizational Citizenship Behavior (OCB) pada Princess Keisha Hotel. Hal ini memiliki makna bahwa perusahaan yang dapat berlaku adil kepada karyawannya dalam segala aturan maupun hasil yang diterima akan menimbulkan perilaku Organizational Citizenship Behavior (OCB) pada karyawan, hubungan ini didukung oleh teori pertukaran sosial yang menyatakan bahwa ketika karyawan telah diperlakukan dengan baik dan adil oleh perusahaannya maka akan cenderung melakukan balas budi dengan berperilaku dan berpartisipasi lebih dalam organisasi.

Hasil penelitian ini mendukung temuan dari Nwibere (2014), membuktikan bahwa keadilan organisasi memiliki pengaruh positif dan signifikan terhadap Organizational Citizenship Behavior (OCB). Ibrahim dan Perez (2014), menunjukkan bahwa keadilan organisasional berpengaruh postitif terhadap organizational citizenship behavior. Roohi dan Feizi (2013), menyimpulkan bahwa keadilan organisasional berpengaruh postitif terhadap organizational citizenship behavior. Menurut Saifi dan Shahzad (2017), Keadilan organisasional memiliki dampak positif yang signifikan terhadap OCB.

Berdasarkan hasil analisis pengaruh kepuasan kerja terhadap Organizational Citizenship Behavior (OCB) diperoleh nilai Signifikansi sebesar 0,008 dengan nilai koefisien beta 0,470 . Nilai Signifikansi $0,008<0,05$ mengindikasikan bahwa $\mathrm{H}_{0}$ ditolak dan $\mathrm{H}_{3}$ diterima. Hasil ini mempunyai arti bahwa kepuasan kerja berpengaruh positif dan signifikan terhadap Organizational Citizenship Behavior (OCB) pada Princess Keisha Hotel. Hal ini memiliki makna bahwa karyawan yang memiliki kepuasan kerja yang tinggi akan menimbulkan perilaku Organizational Citizenship Behavior (OCB) pada karyawan, karena apabila karyawan puas akan mengakibatkan semangat kerja yang tinggi yang dapat membantu pihak perusahaan dalam mencapai tujuan yang diinginkan sehingga karyawan bersedia melakukan pekerjaan melebihi tugas-tugas yang diberikan. Hubungan ini didukung oleh teori pertukaran sosial yang berarti bahwa ketika karyawan telah memiliki kepuasan kerja pada organisasi maka akan sendirinya berperilaku lebih dalam organisasi.

Penelitian ini mendukung beberapa hasil penelitian sebelumnya yang dilakukan oleh Sharma et al. (2011), menyatakan bahwa kepuasan kerja berpengaruh positif dan signifikan terhadap organizational citizenship behavior (OCB). Lembono (2013), juga menyatakan kepuasan kerja berpengaruh positif dan signifikan terhadap OCB, semakin tinggi tingkat kepuasan kerja yang di dapat maka semakin tinggi juga tingkat OCB yang dilaksanakan. Wijaya dan Sutanto (2014), menunjukkan bahwa kepuasan kerja berpengaruh positif dan signifikan terhadap organizational citizenship behavior.

Hasil uji menunjukan bahwa nilai $Z$ hitung sebesar 2,5995 $>1,96$ dengan nilai signifikansi $0,0093<0,05$, yang artinya kepuasan kerja merupakan variabel yang memediasi pengaruh keadilan organisasional terhadap Organizational Citizenship Behavior (OCB) pada Princess Keisha Hotel atau dengan kata lain keadilan organisasional berpengaruh secara tidak langsung terhadap Organizational Citizenship Behavior (OCB) melalui kepuasan kerja. Pengujian sebelumnya menunjukkan pengaruh positif dan signifikan pada pengaruh keadilan organisasional terhadap kepuasan kerja, kepuasan kerja terhadap Organizational Citizenship Behavior (OCB), dan keadilan 
organisasional terhadap Organizational Citizenship Behavior (OCB), sehingga dapat disimpulkan bahwa kepuasan kerja secara parsial memediasi pengaruh keadilan organisasional terhadap Organizational Citizenship Behavior (OCB). Hubungan ini didukung oleh teori pertukaran sosial yang berarti bahwa ketika perusahaan dapat menerapkan keadilan organisasional mampu meningkatkan kepuasan kerja pada karyawan maka dengan sendirinya akan timbul perilaku Organizational Citizenship Behavior (OCB).

Penelitian ini mendukung beberapa hasil penelitian sebelumnya yang dilakukan oleh Saifi dan Shahzad (2017), membuktikan bahwa kepuasan kerja memediasi hubungan antara keadilan organisasional dan OCB. Menurut Widyaningrum (2010), kepuasan kerja terbukti mampu memediasi secara penuh pengaruh keadilan organisasional terhadap OCB. Penelitian dari Najafi et al., (2011), menyatakan bahwa kepuasan kerja dapat memediasi hubungan antara keadilan organisasional dengan OCB. Zadeh et al. (2015), mengatakan bahwa keadilan organisasional berpengaruh terhadap OCB dengan kepuasan kerja sebagai pemediasi.

\section{KESIMPULAN}

Upaya meningkatkan perilaku organizational citizenship behavior (OCB) pada karyawan, perusahaan harus mampu membuat karyawannya melaksanakan tugas melebihi tugas yang diberikan karena karyawan yang mau menyelesaikan tugas melebihi tugasnya diharapkan dapat berkontribusi dalam pencapaian tujuan yang telah ditetapkan oleh perusahaan.

Perusahaan Princess Keisha Hotel hendaknya dapat memberikan kenaikan gaji yang sepantasnya kepada karyawan, hal ini sangat dibutuhkan karyawan karena dengan adanya kenaikan gaji karyawan akan lebih produktif dan dapat memicu terjadinya kenaikan kinerja pada karyawan.

Upaya meningkatkan kepuasan kerja pada karyawan, perusahaan harus mampu memberikan standar pekerjaan yang jelas bagi setiap karyawannya agar merasa puas sehingga dapat menimbulkan semangat kerja yang tinggi yang dapat membantu pihak perusahaan dalam mencapai tujuan yang diinginkan perusahaan.

Penelitian ini dilakukan hanya sebatas pada ruang lingkup perusahaan Princess Keisha Hotel sehingga hasil penelitian ini tidak dapat digunakan pada perusahaan lain dalam sektor jasa sejenis ataupun perusahaan pada sektor lainnya.

Faktor-faktor yang mempengaruhi perilaku Organizational Citizenship Behavior (OCB) dalam penelitian ini hanya keadilan organisasional dan kepuasan kerja, sedangkan masih banyak faktor lain yang dapat mempengaruhi. 


\section{DAFTAR PUSTAKA}

Ahdiyana, Marita. 2013. Dimensi Organizational Citizenship Behavior (OCB) dalam Kinerja Organisasi. Efisiensi-Kajian Ilmu Administrasi, 10(1), hal. 1-10.

Altahayneh, Ziad Lutfi., Aman Khasawneh and Abedalbasit Abedalhafiz. 2014. Relationship between Organizational Justice and Job Satisfaction as Perceived by Jordanian Physical Education Teachers. Canadian Center of Science and Education, 10(4), pp. 131-138.

Anas, Khaidiri. 2013. Pengaruh Kompensasi dan Lingkungan Kerja Terhadap Kepuasan Kerja Karyawan PT. Karya Mitra Muda. Jurnal Manajemen, 2(1), hal. 1-11.

Awang, Roslan and Wan Mohd Rashid Wan Ahmad. 2015. The Impact of Organizational Justice on Organizational Citizenship Behavior in Malaysian Higher Education. Mediterranean Journal of Social Sciences, 6(5), pp. 674678.

Bakotic, D. and Tomislav Babic. 2013. Relationship Between Working Conditions and Job Satisfaction: The Case of Croatian Shipbuilding Company. International Journal of Business and Social Science, 4 (2), pp. 206-212.

Cropanzano, R., David E. Bowen and Stephen W. Gilliland. 2007. The Management ff Organizational Justice. Academy Of Management Perspectives, 21(4), hal. 3438.

Erkutlu, Hakan. 2011. The Moderating Role of Organizational Culture In The Relationship Between Organizational Justice And Organizational Citizenship Behaviors. Leadership and Organization Development Journal, 32(6), pp. 532 -554 .

Farahbod, Farzin., Mohammad Reza A. and Mohadeseh N. J. 2013. Organizational Justice, Employees Trust and Organizational Support. Kuwait Chapter of Arabian Journal of Business and Management Review, 3(2), pp. 74-85.

Fatimah, O., A. M. Amiraa and F. W. Halim. 2011. The Relationships between Organizational Justice, Organizational Citizenship Behavior and Job Satisfaction. Pertanika J. Soc. Sci. \& Hum, 19(S), pp. 115-121.

Gibson, J. L., Donnelly J. H., Ivancevich and J. Mdan Konopaske R. 2012. Organizations: Behavior, structure, processes. McGraw-Hill.

Harper, Pamela J. 2015. Exploring Forms of Organizational Citizenship Behaviors (OCB): Antecedents And Outcome. Journal of Management and Marketing Research, 18(1), pp. 1-16.

Ibrahim, Mohamed E. dan Ann O. Perez. 2014. Effects of Organizational Justice, Employee Satisfaction, and Gender on Employees' Commitment: Evidence from The Uae. International Journal of Business and Management, 9 (2), pp. 45-59.

Ibrahim, Rashidah Mohamad., Aziz Amin and Munir Saleh. 2014. The Link Between Leader-Member Exchange, Organizational Citizenship Behavior and Job 
Satisfaction: A Case Study on Local Government. International Journal of Academic Research in Business and Social Sciences, 4 (5), pp. 313-325.

Indrawan, Dewa Cahyadi dan A.A. Sagung Kertika Dewi. 2014. Pengaruh Kompensasi, Kepemimpinan, dan Lingkungan Kerja Fisik terhadap Kepuasan Kerja Karyawan PT. Cargo Asas International, Denpasar. E-Jurnal Manajemen Universitas Udayana, 3(6), hal. 1767-1779.

Kristanto, S., I.K. Rahyuda dan I.G. Riana. 2014. Pengaruh Keadilan Organisasional terhadap Kepuasan Kerja dan Dampaknya Terhadap Komitmen, dan Intensi Keluar di PT Indonesia Power UBP Bali. E-Jurnal Ekonomi dan Bisnis Universitas Udayana, 3(6), hal. 308-329.

Lee, Ung Hee., Kim Hye Kyoung and Kim Young Hyung. 2013. Determinants of Organizational Citizenship Behavior and Its Outcomes. International Journal Global Business \& Management, 5(1), pp. 54-65.

Lembono, Ardi Y. 2013. Pengaruh Gaya Kepemimpinan Transformasional Dan Transaksional Serta Kepuasan Kerja Terhadap Organizational Citizenship Behavior (OCB) Pada PT Indofood Sukses Makmur Beji Pasuruan. Jurnal Ilmiah Mahasiswa Manajemen, 2(2), hal. 97-102.

Lubis, M. S. 2015. Pengaruh Iklim Organisasi dan Komitmen Organisasi terhadap Pembentukan Organizational Citizenship Behavior (OCB) Karyawan. e-Jurnal Apresiasi Ekonomi, 3 (2), hal. 75 - 84.

Luthans, F. 2006. Perilaku Organisasi, Edisi Sepuluh. Yogyakarta: Andi.

Moorman, R.H. 1991. Relationship Between Organizational Justice and Organizational Citizenship Behaviors: Do Fairness Perceptions Influence Employee Citizenship? Journal of Applied Psychology, 76(6), pp. 845-855.

Mohammad, Jehad., Farzana Quoquab Habib and Mohmad Adnan Alias. 2011. Job Satisfaction and Organisational Citizenship Behaviour: An Empirical Study at Higher Learning Institutions. Asian Academy of Management Journal, 16(2), pp. 149-165.

Mohammed, Fatema and Muath Eleswed. 2013. Job Satisfaction and Organizational Commitment: A Correlational Study in Bahrain. International Journal of Business, Humanities and Technology, 3(5), pp.43-53.

Mustikawati, R. dan I Wayan Suana. 2018. Pengaruh Sinisme Organisasi Dan Keadilan Organisasi Terhadap Komitmen Organisasional. E-Jurnal Manajemen Unud, 7(5), hal. 2380-2409.

Naeem, AT., Freeha Ihsan and Zahid Mahmood. 2014. The Study of Organizational Justice, Violation of Psychological Contract and Its Effect on Job Satisfaction in Paris Industry of Pakistan. International Journal of Academy Research in Business and Social Sciense, 4(12), pp. 244-251.

Najafi, S., Ali Noruzy., Hemin K. A., Sajad Nazari-Shirkouhi and Mohammad Reza Dalvand. 2011. Investigating the Relationship Between Organizational Justice, Psychological Empowerment, Job Satisfaction, Organizational Commitment 
and Organizational Citizenship Behavior: An Empirical Model. African Journal of Business Management, 5(13), pp. 5241-5248.

Nugraha, Satya I., dan I.G.A. Dewi Adnyani. 2018. Pengaruh Budaya Organisasi, Komitmen Organaisasi, dan Kompetensi terhadap Organizational Citizenship Behaviour pada Setda Kota Denpasar. E-Jurnal Manajemen Universitas Udayana, 7(1), hal. 1 - 28.

Nwibere, B. M. 2014. Organizational Justice as a Determinant of Organizational Citizenship Behaviour in the Nigerian in the Niger Delta Region. International Journal of Business and Management, 9(4), pp. 191-205.

Ogut, E., Mehmet Şahin and M. Tahir Demirsel. 2013. The relationship between perceived organizational justice and cyberloafing: Evidence from a public hospital in Turkey. Mediterranean Journal of Social Sciences, 4(10), pp.226233.

Putra, I dan I. Supartha. 2016. Pengaruh Kepemimpinan Transformasional terhadap Kepuasan Kerja dan $O C B$ pada Serene Villas. E-Jurnal Manajemen Universitas Udayana, 5(3), hal. 1718-1744.

Putra, Wisnu Yogeswara dan Made Surya Putra. 2014. Pengaruh Keadilan Organisasi Pada Kepuasan Kerja Dan Turnover Intention Karyawan BPR Di Kabupaten Tabanan. Jurnal Manajemen Udayana, 2(9), pp. 2579-2614.

Putri, F. K. 2015. Pengaruh Keadilan Organisasional dan Motivasi Kerja terhadap Kepuasan Kerja Karyawan Toko Buku Uranus. Agora, 3(2), hal. 245-250.

Rejeki, Umiarti S., I Gede Riana dan Putu Saroyeni Piartini. 2014. Peran Mediasi Kepuasan Kerja Pada Hubungan Kesesuaian Nilai Individu dan Nilai Organisasi Dengan Komitmen Organisasional dan Organizational Citizenship Behavior (Ocb) Karyawan Balai Besar Pom Di Denpasar. E-Jurnal Ekonomi dan Bisnis Universitas Udayana, 3(7), hal. 403-423.

Rini, Dyah P., Rusdarti dan Suparjo. 2013. Pengaruh Komitmen Organisasi, Kepuasan Kerja Dan Budaya Organisasi Terhadap Organizational Citizenship Behavior (OCB) (Studi pada PT. Plasa Simpanglima Semarang). Jurnal Ilmiah Dinamika Ekonomi dan Bisnis, 1(1), hal. 69-88.

Robbins, Stephen P. dan Timothy A. Judge. 2008. Perilaku Organisasi "Organizational Behavior". Edisi 12. Jakarta: Salemba Empat.

Rohayati, Ai. 2014. Pengaruh Kepuasan Kerja Terhadap Organizational Citizenship Behavior: Studi Pada Yayasan Masyarakat Madani Indonesia. Study \& Management Research, 11 (1), hal. 20-38.

Roohi, M and M. Feizi. 2013. Organizational Justice and Organizational Citizenship Behavior in Islamic Azad University. International. Journal of Management research and Review, 3(3), pp. 2513-2521.

SaePung, Wannee., Sukirno and Sununta Siengthai. 2011. The Study of Organizational Citizenship Behavior (OCB) and Job Satisfaction in the Retail Industry in Indonesia. World Review of Business Research, 1(3), pp. 162-178. 
Saifi, Imran Akbar and Khuram Shahzad. 2017. The Mediating Role of Job Satisfaction in the Relationship between Organizational Justice and Organizational Citizenship Behavior. Pakistan Journal of Commerce and Social Sciences, 11(1), pp. 125-145.

Sanhaji, Akhmad., Budi Eko Soetjipto dan Suharto. 2016. Pengaruh Keadilan Organisasi dan Budaya Organisasi terhadap Perilaku Kewargaan Organisasi Melalui Komitmen Organisasi dan Kepuasan Kerja. Jurnal Pendidikan, 1(5), hal. $917-926$.

Santhi, Melda Cahaya N. dan Ni Wayan Mujiati. 2016. Pengaruh Quality of Work Life, dan Motivasi terhadap Kepuasan Kerja Karyawan. E-Jurnal Manajemen Universitas Udayana, 5(11), hal. 7300-7327.

Santika, I. dan I. Wibawa. 2017. Pengaruh Organizational Justice dan Motivasi Kerja terhadap Organizational Citizenship Behavior (OCB). E-Jurnal Manajemen Universitas Udayana, 6(3), hal.1139-1167.

Sharma, Jai Prakash., Naval Bajpai and Umesh Holani. 2011. Organizational Citizenship Behaviour in Public and Private Sector and It's impac on Job Satisfaction: A Comparative Study in Indian Perspective. International Journal of Business and Management, 6(1), pp. 67-75.

Sjahruddin, H. and Armanu Achmad Sudiro Normijati. 2013. Personality effect on organizational citizenship behavior (OCB): trust in manager and organizational commitment mediator of organizational justice in Makassar City Hospitals (Indonesia). European Journal of Business and Management, 5(9), pp. 95-104.

Supartha, Jananda., Wayan Gede Supartha dan Wayan Mudiartha Utama. 2013. Pengaruh Moral Karyawan dan Komitmen Organisasional terhadap OCB dan Kinerja Individual Karyawan (Studi pada Rama Beach Resort \& Villas). EJurnal Ekonomi dan Bisnis Universitas Udayana, 2(11), hal. 43-45.

Suryanatha, A. dan K. Ardana. 2014. Pengaruh Kepemimpinan Transformasional dan Komitmen Organisasi terhadap Kepuasan Kerja Karyawan dan Organizational Citizenship Behavior (OCB) pada Baleka Resort Hotel \& Spa Legian. E-Jurnal Manajemen Universitas Udayana, 3(4), hal. 1155-1170.

Svensson, Jorgen and Marieke van Genugten. 2013. Retaliation Against Reporters of Unequal Treatment: Failing Employee Protection In The Netherlands. Equality, Diversity and Inclusion: An International Journal, 32(2), pp. 129-143.

Swaminathan, Samanvitha dan P. David Jawahar. 2013. Job Satisfaction as A Predictor of Organizational Citizenship Behavior: An Empiral Study. Global Journal of Business Research, 7(1), pp. 71-76.

Tahseen, Nosheena and Muhammad Saeed Akhtar. 2016. Impact of Organizational Justice on Citizenship Behavior: Mediating Role of Faculty Trust. Pakistan Journal of Commerce and Social Sciences, 10(1), pp. 104-121.

Widyaningrum, M.E. 2010. Pengaruh Keadilan Organisasi Terhadap Kepuasan Kerja, Komitmen dan Organisasional Citizenship Behavior Pegawai (Studi Kasus di Rumah Sakit Bersalin Pura Raharja Surabaya) Tahun 2009. Jurnal ekonomi dan bisnis Airlangga (JEBA), 20(1), hal. 100-118. 
Wijaya, Ferry J. dan Eddy Madiono Sutanto (2014). Pengaruh Komitmen Organisasional dan Kepuasan Kerja Karyawan terhadap Organizational Citizenship Behavior (Ocb) di PT Xyz Surabaya. Agora, 2(2), hal. 1574-1579.

Yaqin, Muhammad Ainul. 2013.Pengaruh Kepuasan Kerja dan Komitmen Organisasi terhadap Turnover Intention Karyawan Kjpp Toha, Okky, Heru \& Rekan Cabang Surabaya. Jurnal Ilmu Manajemen, 1(2), hal. 919-930.

Zadeh, Mina Hakak., Dr. M. Reza Esmaili., Dr. F. Tojari and Dr. Ali Z. 2015. Relationship between Job satisfaction, Organizational commitment and Organizational Justice with Organizational Citizenship Behavior in Physical Educators. MAGNT Research Report, 3(2), pp. 199-210. 